\title{
Chronic electroshock: Effects on brain weight, brain chemistry, and behavior'
}

GORDON T. PRYOR, LEON S. OTIS AND EDWARD UYENO

STANFORD RESEARCH INSTITUTE

Minimum or maximum electroshock convulsions administered chronically to rats resulted in increased brain weight, total brain cholinesterase activity, total protein, and total acetylcholinesterase activity depending upon whether or not full convulsions were induced and on the frequency of their induction over a 17-20 week period. Convulsed rats made more errors in an underwater T-maze than rats given subconvulsive shocks or sham controls.

Bennett et al (1964) reported that rats maintained in an "enriched" environment for 80 days developed heavier cortices and higher total activities of cholinesterase (ChE) and acetylcholinesterase (AChE) than littermates raised in isolation. They attributed these changes to the different opportunities for learning under the two conditions. To investigate the possibility that stimulation of the nervous system, per se, without experiential differences, is sufficient to produce these or similar changes, we stimulated the nervous system of rats by repeated electroshocks for 17-20 weeks. Method

We used 78 Wistar rats of both sexes. Animals were housed one per cage and food and water were given ad lib. At 30 days of age, the animals were formed into two groups. Group I was given one treatment per week for 20 weeks and Group II, three treatments per week for 17 weeks. Each group was further divided into three subgroups: a maximal seizure group, a threshold seizure group, and a sham control group.

Electroshock (ES) was delivered via ear clips from a constant current stimulator (60 cps ac for $0.2 \mathrm{sec}$.). Current intensity varied for each animal during the experiment and was re-estimated before each treatment using the procedure of Woodbury \& Davenport (1952). The maximal seizure groups were stimulated with an intensity just sufficient to produce a full tonic-clonic convulsion. The threshold seizure groups were given as much current as necessary to elicit a minimal threshold seizure, characterized by clonus of the vibrissae and ears. The sham control groups received the same treatment as the ES groups except that no current was administered.

Three days after termination of the treatments, all animals were given three behavioral tests. The first two tests-a 2-hr. test of motor activity and a 15-min. "timidity" test (in which time to emerge from a wire cage onto a black table top was measured)-were given to determine whether or not the treatments had resulted in gross changes in motor activity and/or emotionality. The third test-a spatial discrimination learn- ing task in an underwater T-maze-was given to determine whether electroshock stimulation of the brain would result in increased learning ability. Bennett et al (1964) reported that "enriched" environment rats performed better than isolated littermates on a discrimination reversal problem. In the learning test, two trials were given $1 \mathrm{hr}$. apart. The choice made on the first, training, trial was defined as incorrect for all animals; that is, escape was blocked after the choice was made so that the animal had to retrace to the non-preferred side to escape. During the second, test, trial the non-preferred side on trial 1 was defined as correct.

After behavioral testing was completed, the animals were sacrificed; whole brains were removed rapidly and weighed, and stored on dry ice until chemical analyses for $\mathrm{ChE}$ and $\mathrm{AChE}$ activities and percent protein were made.

\section{Results and Discussion}

The results of the experiment are summarized in Table 1. Sexes were combined since the responses to the treatments did not differ significantly between males and females.

In the "timidity" test, the proportion of animals in both threshold groups that emerged was lower than in the sham control and maximal seizure groups, in that order, but the differences were not significant.

There were no significant differences in motor activity scores for animals in Group I. The threshold seizure group of Group II had significantly lower motor activity scores than the sham control and the maximal seizure groups; the latter two did not differ from each other.

For the spatial discrimination test in the underwater $\mathrm{T}$-maze, the maximal seizure groups made fewer correct choices on the test trial than the sham control and the minimal seizure groups, in that order. The differences among the groups were statistically significant only for those animals treated three times a week.

Brain weight increased as a function of the intensity of the treatment and its frequency. For Group I, the differences just failed to reach the 5-percent level of significance. For Group II, the differences were significant well beyond the .001 level of confidence. Since the body weights of the treated animals were generally lower than those of the controls, the increased brain weight of ES animals cannotbe accounted for by differences in body weight between the groups. Also, the absence of any changes in percent protein 
Table 1. Effects of Chronic Administration of Electroshock on Behavior, Brain Weight, and Brain Chemistry

\begin{tabular}{|c|c|c|c|c|c|c|c|c|c|c|}
\hline Frequency & Treatment & $n$ & Timidity $^{a}$ & $\begin{array}{l}\text { Motor } \\
\text { Activity } b\end{array}$ & T-Maze ${ }^{c}$ & $\begin{array}{l}\text { Body } \\
\text { Weight(g) }\end{array}$ & $\begin{array}{l}\text { Brain } \\
\text { Weight(g) }\end{array}$ & $\begin{array}{l}\text { Protein } \\
(\%)\end{array}$ & $\begin{array}{l}\text { ChE } \\
\text { Activity }\end{array}$ & $\begin{array}{l}\text { AChE } \\
\text { Activitye }\end{array}$ \\
\hline One per week & $\begin{array}{l}\text { Snam control } \\
\text { Threshold } \\
\text { Maximal } \\
\text { Significance } f\end{array}$ & $\begin{array}{r}6 \\
13 \\
16\end{array}$ & $\begin{array}{l}0.33 \\
0.31 \\
0.38 \\
\text { N.S. }\end{array}$ & $\begin{array}{l}697 \\
671 \\
526 \\
\text { N.S. }\end{array}$ & $\begin{array}{l}0.67 \\
0.69 \\
0.38 \\
\text { N.S. }\end{array}$ & $\begin{array}{l}366 \\
398 \\
348 \\
<.01 \\
\end{array}$ & $\begin{array}{l}1.95 \\
2.02 \\
2.02 \\
\leq .10 \\
\end{array}$ & $\begin{array}{l}13.8 \\
14.2 \\
13.8 \\
\text { N.S. }\end{array}$ & $\begin{array}{l}3.2 \\
3.2 \\
3.2 \\
\text { N.S. }\end{array}$ & $\begin{array}{c}96.6 \\
98.3 \\
93.2 \\
\leq .01 \\
\end{array}$ \\
\hline Three per week & $\begin{array}{l}\text { Sham control } \\
\text { Threshold } \\
\text { Maximal } \\
\text { Significance } f\end{array}$ & $\begin{array}{l}12^{g} \\
13^{g} \\
12\end{array}$ & $\begin{array}{l}0.50 \\
0.38 \\
0.58 \\
\text { N.S. }\end{array}$ & $\begin{array}{l}684 \\
431 \\
738 \\
<.025 \\
\end{array}$ & $\begin{array}{l}0.45 \\
0.83 \\
0.33 \\
<.05 \\
\end{array}$ & $\begin{array}{l}392 \\
371 \\
377 \\
\text { N.S. }\end{array}$ & $\begin{array}{l}1.99 \\
2.01 \\
2.12 \\
<.001 \\
\end{array}$ & $\begin{array}{l}12.7 \\
13.0 \\
13.1 \\
\text { N.S. }\end{array}$ & $\begin{array}{l}4.4 \\
4.4 \\
4.3 \\
\text { N.S. }\end{array}$ & $\begin{array}{c}109.1 \\
105.0 \\
108.6 \\
\text { N.S. }\end{array}$ \\
\hline
\end{tabular}

(a) Proportion of exits in 15 min. (b) Mean total revolutions in 2 hrs. (c) Proportion of correct choices on trial 2. (d) Moles AcSCh hy drolysed/min/mg of tissue $x 10^{10}$ under our conditions. (e) Moles BuSCh hydrolysed/min/mg of tissue $x 10^{10}$ under our conditions. (f) Based on analysis of variance among groups (no valid comparison can be made between groups treated once per week and three times per week since there were confounding factors present, viz., times of testing, sacrifice and chemical analyses. ( $g$ ) One animal drowned during the spatial discrimination test.

among the groups is evidence against the interpretation that the brain weight changes were due to edema.

There were no significant differences among any of the groups in specific ChE activity (activities per unit weight), indicating that total activity (activity per whole brain) increased in proportion to the increases in tissue weight. There was a decrease in the specific activity of AChE for the group receiving maximal seizures once a week, and a slight, though insignificant, decrease in the specific activity of this enzyme for both groups treated three times per week. This suggests that total $\mathrm{AChE}$ activity did not increase in proportion to the increase in weight in the weekly group, whereas ES three times a week was sufficient to produce enzyme changes commensurate with the weight changes. Independent changes in weight and enzyme activity were also reported by Bennett et al (1964).

We tentatively interpret these results as follows: Electrical stimulation of the brain is sufficient to increase brain weight and the activity of enzymes thought to be involved in neural transmission. These changes are related either to the intensity of the electroshock current or to the occurrence or non-occurrence of a full convulsion or both; frequency (and possibly the spacing) of electroshock stimulation is also a factor. Changes in brain weight and enzyme activities, however, do not necessarily reflect an increased learning ability as found after patterned stimulation from an "enriched environment." This may be due to the diffuse nature of the stimulation resulting from ES and the well known but unexplained amnesic effect of electroconvulsive shock on recently learned responses.

The behavioral results generally agree with published reports on the effects of multiple ESs on behavioral measures similar to those used in this experiment. The increase in "timidity" and reduction in motor activity by the threshold groups are in accord with data reported by McGaugh \& Madsen (1964), showing that ES increases the number of immobility responses, defined as freezing and crouching. They also found that subconvulsive shocks were more effective in this respect than convulsive shocks.

The differences in learning a relatively simple spatial discrimination among the groups deserves some comment. Weissman (1963) found that electroconvulsive shock produced retrograde amnesia in a one-trial avoidance task, whereas subconvulsive currents had no such effect, a result consistent with our finding that only the maximal seizure groups had impaired performance. Thus, maximal seizure animals may not have been able to consolidate learned habits normally accumulated from daily living that may have been useful during problem solving in the maze; each ES could have erased such experiences as they occurred. The minimal seizure groups would not be expected to accumulate such a deficit since memory deficit has not been demonstrated in animals given subconvulsive electroshock.

\section{References}

Bennett, E. L., Diamond, M. C., Krech, D., \& Rosenzweig, M. R. Chemical and anatomical placticity of brain. Science, 1964, 146, 610-619.

McGaugh, J. L., \& Madsen, M. C. Amnesic and punishing effects of electroconvulsive shock. Science, 1964, 144, 182-183.

Weissman, A. Effect of electroconvulsive shock and seizure pattern on retrograde amnesia. J. comp. physiol. Psychol., 1963, 56, 806-810.

Woodbury, L. A., \& Davenport, V. D. Design and use of a new electroshock seizure apparatus, and analysis of the factors altering seizure threshold and pattern. Arch. Intl. Pharmacodyn. Therap., 1952, 92, 97-107.

\section{Note}

1. This research was supported by Contract Nonr-2993(00) be-tween the Office of Naval Research and Stanford Research Institute- 